\title{
PENERAPAN TIPE JIGSA $W$ UNTUK MENINGKATKAN MOTIVASI DAN HASIL BELAJAR SISWA PADA AKUNTANSI PERUSAHAAN DAGANG
}

\section{IMPLEMENTATION TYPE JIGSAW TO IMPROVE STUDENT'S MOTIVATION AND LEARNING OUTCOMES IN ACCOUNTING OF TRADING COMPANIES}

\author{
Oleh: \\ Harly Sintya Desy \\ Pendidikan Akuntansi Universitas Negeri Yogyakarta \\ harlysintya24@gmail.com \\ Isroah \\ Staf Pengajar Jurusan Pendidikan Akuntansi Universitas Negeri Yogyakarta
}

\begin{abstract}
Abstrak
Penelitian dilakukan untuk mengetahui: Peningkatan Motivasi dan Hasil Belajar Siswa kelas XI AK 3 SMK N 1 Depok tahun ajaran 2017/2018. Teknik pengumpulan data yaitu dengan Observasi Partisipatif, Angket dan Tes. Teknis analasis data adalah analisis data kuantitatif. Hasil penelitian menunjukan peningkatan Motivasi Belajar Siswa dengan observasi dari Prasiklus - Siklus I sebesar 6,75\% dan dari Siklus I ke Siklus II sebesar 9,68\%. Peningkatan Motivasi Belajar Siswa dari Siklus I ke Siklus II berdasarkan angket adalah sebesar 4,85\%. Pada Siklus I Hasil Belajar Siswa belum mencapai kriteria minimal ketuntasan sebesar 75\% yaitu sebesar 16,67\%. Pada Siklus II Hasil Belajar Siswa sudah mencapai kriteria minimal ketuntasan $75 \%$ yaitu sebesar 93,33\%.
\end{abstract}

Kata Kunci: Motivasi Belajar Siswa, Hasil Belajar Siswa, Model Pembelajaran Kooperatif tipe Jigsaw.

\begin{abstract}
This research aimed to improve student's motivation and learning outcomes of class XI AK 3 SMK Negeri 1 Depok in the academic year of 2017/2018. The data collection techniques used observation sheets, questionnaire and test. The data analysis technique in this research was quantitative data. The result of this research shows the improvement on student's learning motivation by observation from pre cycles - cycles I was 6,75\% and cycles I to cycles II was 9,68\%. The improvement on student's learning motivation by questionnaire was 4,85\%. At the cycles I, the student's learning outcomes had not met the KKM (75\%), which was $16,67 \%$. At the cycles II, the student's learning outcomes had met the KKM (75\%), which was 93,33\%.
\end{abstract}

Keywords: Student's Learning Motivation, Student's Learning Outcomes, Cooperative Learning Method Type Jigsaw 


\section{PENDAHULUAN}

Sugihartono (2012:3) pendidikan adalah suatu usaha yang dilakukan secara sadar dan sengaja untuk mengubah tingkah laku manusia baik secara individu maupun kelompok untuk mendewasakan manusia melalui upaya pengajaran dan pelatihan. Dengan mengupayakan pengajaran yang bervariasi dan pelatihan yang berkualitas diharapkan mampu membantu siswa dalam mencapai tujuan belajar secara matang dan optimal serta meningkatkan semangat dan motivasi untuk belajar dengan didukung oleh guru.

R. Ibrahim (2010:27) motif atau biasa juga disebut dorongan atau kebutuhan merupakan sesuatu tenaga yang berada pada diri individu atau siswa yang mendorongnya untuk berbuat mencapai suatu tujuan. Meningkatkan motivasi belajar dapat dilakukan oleh guru dengan hal berikut, seperti: (1) menggunakan cara atau metode dan media mengajar yang bervariasi sehingga kebosanan dapat dikurangi atau dihilangkan, (2) memilih bahan yang menarik minat dan dibutuhkan siswa karena akan menarik perhatiannya, dengan demikian akan membangkitkan motif untuk mempelajarinya. (3) memberikan sasaran antara, seperti ujian semester, tengah semester, ulangan harian, kuis, dan sebagainya, (4) memberikan kesempatan untuk sukses, (5) diciptakan suasana belajar yang menyenagkan.

Rita Eka Izzaty dkk (2013:17) perkembangan individu merupakan pola gerakan atau perubahan yang secara dinamis dimulai dari pembuahan atau konsepsi dan terus berlanjut sepanjang siklus kehidupan manusia yang terjadi akibat dari kematangan dan pengalaman. Pembelajaran yang berpusat pada guru tidak lagi sesuai dengan perkembangan siswa pada saat ini. Model pembelajaran akhir-akhir ini banyak berkembang model pembelajaran siswa aktif. Artinya pembelajaran yang diterapkan di kelas menuntut siswa untuk aktif dalam mengikuti proses pembelajaran. Semakin siswa aktif dalam mengikuti proses belajar dikelas maka rasa ingin tahu siswa akan semakin tinggi. Hal inilah yang perlu dilakukan guru untuk menerapkan strategi pembelajaran yang tepat dan sesuai dengan kebutuhan siswa. Strategi yang tepat sangat berpengaruh pada motivasi dan hasil belajar yang diperoleh. Kesesuaian strategi pembelajaran dengan tujuan belajar harus dilakukan agar siswa dalam mencapai tujuan belajar dapat berhasil dan optimal.

Miftahul Huda (2012. mendefinisikan pembelajaran kooperatif sebagai pembentukan kelompok-kelompok kecil yang terdiri dari siswa-siswa yang dituntut untuk bekerja sama dan saling meningkatkan pembelajaran siswa-siswa lain. Model pembelajaran kooperatif memiliki beberapa macam antara lain Jigsaw, Student Teams-Achievment Division (STAD), Team Game Tournament (TGT), Cooperative Integrated Reading and Composition (CIRC), Team Assisted Individualization (TAI), Group Investigation (GI), Learning Together (LT), Complex Instruction (CI), dan Structure Dyadic Methhods (SDM).

Slavin (2005:235) Jigsaw merupakan model pembelajaran kooperatif, dengan siswa belajar dalam kelompok kecil yang terdiri dari 4-6 orang secara heterogen. Materi pembelajaran yang diberikan kepada siswa berupa teks dan setiap anggota bertanggungjawab atas ketuntasan bagian materi pelajaran yang harus dipelajari. Kelompok yang telah dibentuk akan memiliki tugas atau tanggung jawab sesuai dengan pembagiannya. Masing-masing anggota kelompok akan bertanggungjawab baik itu per bab maupun setiap sub bab. Setiap anggota akan dipisahkan dan kemudian akan dikelompokan dengan kelompok ahli yang bertanggungjawab atas materi tersebut. Tujuan kelompok ahli ini adalah setiap individu akan membahas dan memperdalam materi yang harus dikuasai, ketika sudah menguasai maka akan dikembalikan ke kelompok asal. Dengan demikian, harapannya adalah kelompok ahli 
dapat menjelaskan ke teman-teman ke kelompok asal.

Perusahaan Dagang adalah perusahaan yang kegiatannya melakukan pembelian barang dagang untuk dijual kembali tanpa mengubah bentuknya. Akuntansi Perusahaan Dagang adalah akuntansi yang mempelajari tentang bagaimana cara melakukan pembukuan atau penjurnalan pada perusahaan dagang. (Toto Sucipto, 2015:86). Perusahaan yang dapat digolongkan sebagai perusahaan dagang antara lain distributor, agen tunggal, pengecer, toko swalayan, toko serba ada dan lain-lain. Pada perusahaan dagang terdapat pula pembelian barang dagang yang berulang-ulang dan menimbulkan biaya pengangkutan, potongan pembelian, dan retur pembelian. Demikian pula dalam penjualannya, pada perusahaan jasa biasanya terjadi penjualan jasa, yang tidak perlu biaya pengangkutan. Pada perusahaan dagang, penjualan mengakibatkan timbulnya biaya angkut penjualan dan kadang-kadang terjadi retur penjualan. Selama ini dalam pengerjaan soal-soal akuntansi siswa mengaku mengerjakannya sendiri sehingga belajar materinya pun secara individu. Hal tersebutlah yang menyebabkan kendala tersendiri bagi siswa. Ketika siswa mengalami kendala dan kesulitan untuk memahami materi maka akan sungkan untuk bertanya kepada teman yang lebih mengetahui. Jika hal tersebut berlanjut maka siswa yang mengalami kesulitan belajar akan memiliki hasil belajar yang tidak sesuai harapan.

Berdasarkan hasil wawancara yang dilakukan pada tanggal 6 Maret 2017 dengan 7 siswa dari 31 siswa atau $22,58 \%$ kelas XI AK 3 SMK Negeri 1 Depok bahwa hampir $50 \%$ setiap kelas masih mengikuti remidi baik itu ulangan harian maupun ujian akhir semester. Beberapa faktor yang menyebabkan hal tersebut terjadi adalah karena motivasi siswa untuk belajar akuntansi perusahaan dagang masih rendah, siswa sulit untuk memahami materi yang secara teori, siswa masih menghafal format untuk menghitung akuntansi perusahaan dagang, standar KKM yang terbilang cukup tinggi yaitu 80 sedangkan untuk menyelesaikan soal akuntansi perusahaan dagang diperlukan pemahaman bukan penghafalan. Selain itu, terdapat faktor eksternal seperti pengaruh teman, seperti mengobrol di kelas, banyak jam kosong, cara mengajar menggunakan metode ceramah kemudian mengerjakan soal dan juga langsung mengerjakan soal tanpa pengantar materi. Beberapa dari hasil pekerjaan siswa juga belum disampaikan kembali kepada siswa, sehingga siswa kurang mengetahui hasil apa yang sudah didapat dan hal-hal apa saja yang perlu diperbaiki dan ditingkatkan.

Berdasarkan penelitian yang dilakukan sebelumya oleh M. Aditya Indra Kesuma pada Tahun 2015 dengan judul "Implementasi Model Pembelajaran Kooperatif Teknik Jigsaw untuk Meningkatkan Motivasi Belajar Akuntansi Siswa Kelas XI IPS 1 Madrasah Aliyah Negeri Pakem Sleman Tahun Ajaran 2014/2015", dapat meningkatkan Motivasi Belajar Akuntansi siswa kelas XI IPS 1 Madrasah Aliyah Negeri Pakem Sleman Tahun Ajaran 2014/2015 yang dibuktikan dengan adanya peningkatan persentase skor Motivasi Belajar Akuntansi dari sebelum Implementasi Teknik Jigsaw sebesar $72,71 \%$ meningkat sebesar $3,12 \%$ menjadi 75,83 di siklus I. Peningkatan juga terjadi pada siklus I ke siklus II yaitu sebesar $6,05 \%$ atau dari $75,83 \%$ pada siklus I menjadi $81,88 \%$ pada siklus II.

Berdasarkan hasil wawancara yang peneliti lakukan dengan seorang Guru Akuntansi pada tanggal 6 Maret 2017, hasil belajar siswa kelas XI SMK Negeri 1 Depok sekitar $50 \%$ dapat meningkat untuk kemampuan di bidang akuntansi khususnya di kompetensi dasar akuntansi perusahaan dagang. Hasil ulangan harian siswa terdapat 14 siswa atau $45,16 \%$ belum mencapai KKM dan 17 siswa atau 54,84\% sudah mencapai KKM tetapi belum maksimal $(\mathrm{KKM}=80)$. Maka dari itu, perlu 
peningkatan kualitas dan variasi model pembelajaran yang diterapkan untuk kompetensi dasar Akuntansi Perusahaan Dagang Berdasarkan kondisi yang telah dipaparkan maka peneliti melakukan Penerapan Model Pembelajaran Cooperative Learning Tipe Jigsaw untuk Meningkatkan Motivasi Belajar Siswa dan Hasil Belajar Siswa Kompetensi Dasar Akuntansi Perusahaan Dagang Kelas XI AK 3 SMK Negeri 1 Depok Tahun Ajaran 2017/2018".

\section{METODE PENELITIAN \\ Jenis Penelitian}

Penelitian ini termasuk Penelitian Tindakan Kelas (PTK) atau dalam bahasa inggris adalah Classroom Action Research (CAR). Muslich (2011:7) menyatakan bahwa penelitian tindakan merupakan penelitian yang bersifat partisipatif dan kolaboratif. Partisipatif yaitu penelitian tindakan dilakukan sendiri oleh peneliti. Dalam hal ini peneliti memulai penelitian dari penentuan topik, merumuskan masalah, perencanaan, pelaksanaan, menganalisis, dan melaporkan. Penelitian bersifat kolaboratif karena dalam pelaksanaan penelitian khususnya pengamatan, diperlukan teman sejawat untuk membantu merekap data yang terjadi di kelas.

\section{Tempat dan Waktu Penelitian}

Penelitian Tindakan Kelas dilaksanakan di SMK Negeri 1 Depok Jalan Ring Road Utara, Maguwoharjo, Depok, Sleman, Daerah Istimewa Yogyakarta 55282. Penelitian dilakukan pada bulan Oktober tahun 2017.

\section{Subjek dan Objek Penelitian}

Subjek penelitian ini adalah siswa kelas XI AK 3 SMK Negeri 1 Depok yang berjumlah 31, sedangkan objek dalam penelitian ini adalah Motivasi Belajar Siswa dan Hasil Belajar Siswa pada kompetensi dasar akuntansi perusahaan dagang melalui penerapan model pembelajaran kooperatif tipe Jigsaw.

\section{Teknik Pengumpulan Data}

Teknik pengumpulan data yaitu dengan Observasi Partisipatif, Angket dan Tes. Peneliti dalam melakukan penelitian, berkolaborasi dengan 2 observer untuk mengamati sejumlah 31 siswa.

\section{Instrumen dan Teknik Analisis Data}

Instrumen pada penelitian ini adalah lembar observasi angket, tes, dan dokumentasi. Lembar observasi dan angket digunakan untuk memperoleh data Motivasi Belajar Siswa. Sedangkan tes digunakan untuk memperoleh data Hasil Belajar Siswa. Teknik analisis data yaitu analisis data kuantitatif dan deskriptif.

HASIL PENELITIAN DAN PEMBAHASAN

Penerapan Pembelajaran Kooperatif Tipe Jigsaw dalam Meningkatkan Motivasi Belajar Siswa Kelas XI AK 3 SMK Negeri 1 Depok.

Tabel 1. Skor Motivasi Belajar Siswa berdasarkan Observasi

\begin{tabular}{|l|c|c|c|}
\hline \multirow{2}{*}{ No } & \multicolumn{3}{|c|}{ Skor } \\
\cline { 2 - 4 } & Prasiklus & Siklus I & Siklus II \\
\hline 1. & $63,89 \%$ & $72,78 \%$ & $81,67 \%$ \\
\hline 2. & $70,00 \%$ & $76,67 \%$ & $86,67 \%$ \\
\hline 3. & $70,00 \%$ & $73,33 \%$ & $84,44 \%$ \\
\hline 4. & $73,89 \%$ & $75,00 \%$ & $82,78 \%$ \\
\hline 5. & $63,33 \%$ & $72,22 \%$ & $84,44 \%$ \\
\hline 6. & $60,00 \%$ & $70,00 \%$ & $77,78 \%$ \\
\hline 7. & $60,00 \%$ & $68,33 \%$ & $78,33 \%$ \\
\hline $\begin{array}{l}\text { Rata- } \\
\text { rata }\end{array}$ & $65,87 \%$ & $72,62 \%$ & $82,30 \%$ \\
\hline
\end{tabular}

Berdasarkan tabel 1 menunjukan peningkatan skor Motivasi Belajar Siswa dari Pra Siklus ke Siklus I sebesar 6,75\% dan dari Siklus I ke Siklus II sebesar 9,68\%. 
Tabel 2. Skor Motivasi Belajar Siswa berdasarkan Angket

\begin{tabular}{|l|r|r|}
\hline \multirow{2}{*}{ No } & \multicolumn{2}{|c|}{ Skor } \\
\cline { 2 - 3 } & Siklus I & \multicolumn{1}{c|}{ Siklus II } \\
\hline 1 & $75,00 \%$ & $84,17 \%$ \\
\hline 2 & $76,67 \%$ & $79,44 \%$ \\
\hline 3 & $75,42 \%$ & $78,33 \%$ \\
\hline 4 & $76,94 \%$ & $80,83 \%$ \\
\hline 5 & $73,54 \%$ & $77,29 \%$ \\
\hline 6 & $72,78 \%$ & $78,33 \%$ \\
\hline 7 & $70,56 \%$ & $76,39 \%$ \\
\hline
\end{tabular}

Berdasarkan tabel 2 terdapat peningkatan Motivasi Belajar Siswa kelas XI AK 3 SMK Negeri 1 Depok. Peningkatan terjadi sebesar $4,85 \%$ yaitu dari Siklus I sebesar $74,41 \%$ ke Siklus II sebesar 79,26\%.

\section{Penerapan Pembelajaran Kooperatif Tipe Jigsaw dalam Meningkatkan Hasil Belajar Siswa Kelas XI AK 3 SMK Negeri 1 Depok.}

Berdasarkan hasil penelitian yang sudah dilakukan, menunjukan bahwa penerapan model pembelajaran kooperatif tipe Jigsaw di kelas XI AK 3 SMK Negeri 1 Depok dapat meningkat hasil belajar siswa pada mata pelajaran pengantar akuntansi kompetensi dasar akuntansi perusahaan dagang. Berikut hasilnya:

\section{Tabel 3. Hasil Belajar Siswa}

\begin{tabular}{|l|c|c|}
\hline Rata-rata & 65.30 & 91.18 \\
\hline Nilai Tertinggi & 90.91 & 100.00 \\
\hline Nilai Terendah & 31.82 & 53.87 \\
\hline Jumlah Nilai $>80$ & 5 & 28 \\
\hline $\begin{array}{l}\text { Persentase } \\
\text { Ketuntasan }\end{array}$ & $16,67 \%$ & $93,33 \%$ \\
\hline
\end{tabular}

Perolehan persentase ketuntasan hasil belajar di siklus I belum mencapai kriteria keberhasilan yang telah direncanakan, yaitu $16,67 \%$ dari kriteria keberhasilan 75\%. Meskipun demikian, secara keseluruhan hasil persentase ketuntasan hasil belajar setelah diterapkannya model pembelajaran kooperatif tipe Jigsaw sudah berhasil mengalami peningkatan mulai dari siklus I ke siklus II. Siklus II diperoleh hasil 93,33\% sehingga telah mencapai kriteria minimal sebesar $75 \%$.

Berdasarkan hasil belajar siswa sebelum diterapkannya pembelajaran kooperatif tipe Jigsaw pada siklus I dan siklus II mengalami peningkatan. Hasil belajar siswa siklus I lebih baik dari siklus I. peningkatan tersebut terjadi karena beberapa faktor seperti proses adaptasi, waktu pengerjaan soal, suasana atau keadaan siswa, dan materi setiap siklus berbeda. Pada siklus I, siswa secara keseluruhan belum bisa beradaptasi dengan tipe Jigsaw. Masih terlihat beberapa siswa pada saat berdiskusi fokusnya tidak pada materi, dan juga belum mempersiapkan materi dengan baik. Pada siklus II, siswa sudah mengetahui hal apa yang akan dilakukan dan juga sudah mengerti secara teknis tipe Jigsaw dan sebelum pembelajaran siswa sudah benarbenar menyiapkan materi yang akan dipelajari serta lebih aktif untuk bertanya ketika tidak memahami materi yang telah didiskusikan.

\section{SIMPULAN DAN SARAN \\ Simpulan}

Penerapan Model Pembelajaran Kooperatif Tipe Jigsaw dapat Meningkatkan Motivasi Belajar Siswa kelas XI AK 3 SMK Negeri 1 Depok. Peningkatan Motivasi Belajar Siswa tersebut terlihat pada pertambahan pencapaian indikator Motivasi Belajar Siswa pada masing-masing siklusnya. Berdasarkan observasi partisipatif menunjukan sebesar $65,87 \%$ naik $6,75 \%$ menjadi $72,62 \%$ pada siklus I, kemudian pada siklus II mengalami peningkatan sebesar $9,68 \%$ yang awalnya siklus I adalah $72,62 \%$ maka menjadi $82,30 \%$. Berdasarkan angket terdapat hasil Motivasi Belajar Siswa adalah $74,41 \%$ naik $4,85 \%$ menjadi $79,26 \%$. Hasil Belajar Siswa sebelum diterapkannya model pembelajaran kooperatif tipe Jigsaw adalah 54,84\% kemudian meningkat hingga $93,33 \%$. 


\section{Saran}

a. Bagi Guru

Perlu lebih mematangkan persiapan untuk menerapkan pembelajaran kooperatif tipe Jigsaw karena banyak perlengkapan dan beberapa teknis yang memerlukan panduan ketika belum terbiasa menggunakan tipe Jigsaw tersebut. Saat mengerjakan soal guru lebih tegas dalam mengawasi agar tidak terjadi kerja sama yang dilakukan untuk soal yang seharusnya harus dikerjakan secara mandiri. Guru lebih komunikatif lagi kepada siswa agar siswa merasa paham dan jelas saat penyampaian materi dan perlu bervariatif dalam metode mengajar agar siswa tidak jenuh.

b. Bagi Siswa

\section{Siswa}

diharapkan

lebih

mempersiapkan diri dengan belajar seluruh materi. Siswa perlu membiasakan diri untuk mengerjakan soal-soal secara mandiri dan mengerjakan secara berkelompok saat mendapatkan soal berkelompok. Siswa perlu fokus dengan menyimpan Handphone.

c. Bagi Peneliti Selanjutnya

Peneliti yang akan melakukan penelitian, pada tahap observasi harus lebih detail agar sesuai dengan permasalahannya. Peneliti harus benarbenar menyusun waktu yang tepat agar waktu dan jadwal yang ditentukan sesuai dan berjalan secara efektif dan efisien.

\section{DAFTAR PUSTAKA}

Huda, Miftahul. (2012). Cooperative Learning. Yogyakarta: Pustaka Pelajar.

R. Ibrahim. (2010). Perencanaan Pengajaran. Jakarta: Rineka Cipta.

Kesuma, M. Aditya Indra. (2015). Implementasi Model Pembelajaran Kooperatif Teknik Jigsaw untuk Meningkatkan Motivasi Belajar Akuntansi Siswa Kelas XI IPS 1 Madrasah Aliyah Negeri Pakem Sleman Tahun Ajaran 2014/2015. Skripsi. Yogyakarta: Fakultas Ekonomi Universitas Negeri Yogyakarta.

Muslich, M. (2011). Melaksanakan PTK Penelitian Tindakan Kelas Itu Mudah Classroom Action Research. Jakarta: Bumi Aksara.

Rita Eka Izzaty dkk. (2013). Perkembangan Peserta Didik. Yogyakarta: UNY Press.

Slavin, Robert E. (2005). Cooperative Learning: Theory, Research and Practice. London: Allymand Bacon.

Sugihartono. (2013). Psikologi Pendidikan. Yogyakarta: UNY Press.

Sucipto, Toto. (2015). Akuntansi Perusahaan Jasa dan Dagang. Bogor: Yudhistira. 